\title{
МОВОЗНАВСТВО
}

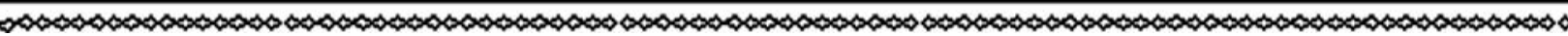

УДК 811.111

https://doi.org/10.33989/2524-2490.2020.33.228238

VALENTYNA VOSKOBOINYK

ORCID 0000-0003-3990-3082

(Полтава) (Poltava)

Place of work: Poltava V. G. Korolenko National Pedagogical University

Country: Ukraine

Email: suc7us@ukr.net

\section{THE STUDY OF THE MORPHOLOGICAL STRUCTURE OF WORDS WITHIN THE FRAMEWORK OF COGNITIVE MORPHOLOGY}

У статті розглянуто основні засади когнітивного підходу до аналізу мовних одиниць. Мета статті - установити основні принципи когнітивної морфології, які можна застосовувати при аналізі морфологічної структури слова. Запропоновано використати методику фреймового моделювання для аналізу морфологічної структури слова. Це дослідження буде корисним для тих, хто працюе в руслі когнітивної морфологї.

Ключові слова: когнітивна граматика; когнітивна морфологія; морфема; фрейм; фреймове моделювання; когнітивні механізми.

Modern research of such multifunctional phenomenon of human consciousness as language is based primarily on connecting different kinds of knowledge. The linguistic branch that has appeared as a result of interaction of several sciences, including cognitology, cognitive psychology, linguistic semantics, ethnolinguistics, neurolinguistics, psycholinguistics, and culture studies, is called cognitive linguistics. It studies the role of language in human cognitive activity. The cognitive approach to the analysis of different language units has led to the growth of separate branches of cognitive linguistics with their own principles and methods of investigation, such as cognitive grammar (R. Langacker), cognitive onomasiology (О. Селіванова), cognitive semantics (R. Jackendoff, A. Wierzbicka), cognitive pragmatics (T. Dijk, J. Nuyts), cognitive conceptology (C. Воркачёв, Г. Слышкин).

The founder of cognitive grammar that studies grammar as a symbolic phenomenon is considered to be R. Langacker (Langacker, 1987). Langacker's works have encouraged other linguists to research grammatical structures from cognitive perspective, among them G. Lakoff, K. Shinichiro, G. Fauconnier, M. Rickheit, and N. Mandelblit. However, neither R. Langacker, nor his followers have distinguished clearly the application of cognitive grammar rules to morphology and syntax, with consideration of their peculiarities as the parts of cognitive grammar. Therefore, the influence of cognitive mechanisms on the morphological structure of words needs to be investigated.

The aim of the article is to establish the main principles of cognitive morphology grounded on cognitive grammar and find the linguistic methods that can be used for the analysis of the morphological structure of any word from the cognitive perspective.

Cognitive grammar as the branch of cognitive linguistics hypothesizes that grammar, semantics, and lexicon exist on a continuum instead of as separate processes altogether (Langacker, 1987, p. 1). Cognitive linguistics in general and cognitive grammar in particular are obliged to N. Chomsky, whose generative grammar made linguists investigate language inside of us because "language is a mirror of mind in a deep and signifi- 
cant sense" (Chomsky, 1975, p. 4). By studying the properties of natural languages, their structure, organization, and use, we may learn something about human nature. Grammar is defined by N. Chomsky as acquisition of the specific cognitive structure that is put to use, interacting with other mechanisms of mind, in speaking and understanding language (Chomsky, 1975, p. 28).

The founder of cognitive grammar R. Langacker equates grammar of language with certain linguistic abilities (mental, perceptual, and physical). He defines grammar as "those aspects of cognitive organization in which resides a speaker's grasp of established linguistic convention. It can be characterized as "a structured inventory of conventional linguistic units" (Langacker, 1987, p. 57). Cognitive grammar posits just three basic types of structures: semantic, phonological, and symbolic. The last one combines the previous two (Langacker, 1987, p. 76). Grammatical structures do not constitute an autonomous formal system; they are inherently symbolic. Lexicon and grammar form a continuum of symbolic elements. Like lexicon, grammar provides for the structuring and symbolization of conceptual content, and thus it is imagic in character. When we use a particular grammatical unit, we select a particular image to structure the conceived situation - by means of alternate images - for purposes of thought or expression" (Langacker, 1987, p. 110).

In cognitive grammar, meaning equates conceptualization leading to cognitive processing. All grammatical units, including grammatical classes, grammatical morphemes, and grammatical constructions are symbolic units that have semantic content, if the semantic pole is suppressed, then the symbolic relationship ceases to exist, and what remains is nothing but undifferentiated phonological structure (Langacker, 1987, p. 85). Furthermore, syntax is closely connected with semantics.

Morphology is a part of grammatical theory that faces two segmental units: the morpheme and the word. The morpheme is a small meaningful unit into which a word form may be divided. Any word can be divided into morphemes, for example, the word form underwriter can be divided into three morphemes: under- + write $+-e r$, each with a special meaning of its own. Morphemes have associative and derivational meanings, which form the lexical meaning of the word through nominative and semantic changes. There are two types of morphemes: segmental ones consisting of phonemes (roots, affixes) and suprasegmental ones, which do not exist by themselves but are realized together with segmental units and express different modification meanings reflected on the strings of segmental units (zero morphemes).

The morphological system of language reveals its properties through morphological units. The cognitive approach to the analysis of the morphological structure of words assumes identifying cognitive mechanisms affecting morphological rules, peculiarities, and functions of morphological units - the morpheme and the word. These tasks can be fulfilled by a separate linguistic branch called cognitive morphology, which also has something to say. Its main goal is to consider morphological units as a result of conventional symbolization and categorization of conceived reality and human experience.

As any science, cognitive morphology should have its own principles. To our mind, its main principles must be grounded, first of all, on the principles of cognitive grammar with consideration of its application to investigating the morphological structure of words. Having analyzed the theoretical prerequisites of cognitive grammar, we have formulated seven principles of cognitive morphology.

The first main principle assumes investigation of morphological units in the light of human experience, cognitive processes of man and his/her vision, because word meanings reflect not only processes, phenomena, objects, qualities but also fragments of human experience and knowledge. Even the meaning of the smallest unit - the morpheme - has limited language representation, but as a component of a word, it forms its conceptual structure reflecting different situations of human experience. Sometimes the morpheme does not manifest experienced events with the help of explicit means. Let us consider the suffixed morpheme -er with the meaning of an agent which can be joined only with those 
verb-stems that denote people's activity (perception, professional, physical, or mental activity, etc): teacher - a person who teaches, admirer - someone who admires, runner - a person who runs, esp. in a race.

The second principle states that morphological units have prototype structures. In cognitive morphology, derivational morphemes are very essential for the categorization process. They have a specific categorial meaning (Полюжин, 1999, p. 32). Because of the categorization process or classification, the designator acquires one of the meanings of the onomasiologic categories (the meaning of an object for nouns, the meaning of the process for verbs, and the meaning of quality for adjectives). This can be illustrated by suffix -ish which can be joined with adjective stems denoting characteristics of colour: reddish-somewhat red, tinged with red; greenish - somewhat green, tinged with green. Our experience is expressed in the form of categories. We cannot "get beyond" our categories and have a purely uncategorized and unconceptualized experience ... Each prototype is a neutral structure that permits us to do some sort of inferential or imaginative task relative to a category" (Lakoff, 1999, p. 19).

The third principle claims that the morphological structure of a word from a certain language depends on the peculiarities of this language. Consider the British variant of English suffix -our with the meaning of quality and condition that equals to suffix -or in American English while coinciding with the suffix -or denoting an object or agent: honour (BrE) - honor (AmE), behaviour (BrE) - behavior (AmE).

The fourth principle considers the fact that while analyzing the morphological structure of words, it is necessary to pay attention to semantics as grammatical rules depend partially on semantic properties of lexical units. As the example, we can give the grammatical category of number of nouns: we can form the plural mainly from countable nouns (names of objects, things, and people): tables, books, pencils, doctors. However, abstract nouns (kindness, peace, pleasure, courage) are not used in the plural. But "the word doesn't have a meaning in itself; rather, it has a meaning potential, and it is only within a complete discourse and in the context that meaning will actually be produced" (Fauconnier, 1997, p. 37). Thus, symbolic units are formed only through unification of semantic, morphologic, and syntactic components.

According to the fifth principle, semantic structures should be characterized with the reference to the ways of interiorisation of reality. Morphological units should be studied with consideration of human cognitive abilities that are manifested through understanding the morphological structure of words. The knowledge of this structure helps a speaker use language rules. It results in understanding unknown or new words from meanings of their components. So the meaning of the word "environmentalist" - "one devoted to protecting the ecological balance of the earth" is quite clear if we know the meanings of its components: environmental - referring to surroundings which affect the growth, development, and existence of living beings and suffix -ist with the meaning of an agent.

The sixth principle is identification of conventional links among conceptual structures through metaphoric and metonymic processes, which allow "conventional mental imagery from sensorimotor domains to be used for domains of subjective experience" (Lakoff, 1999, p. 45). The following English proverbs can serve as the examples of metaphor: Time is the best healer. Ill news flies fast. Great talkers are little doers.

The seventh principle of cognitive morphology is its imaginary character. When we use morphemes, we choose a certain image for outlining the perceived situation in the speech. These imagic schemas participate in the creation of wider, more complex and dynamic images in our mind. "Schemas are frames created unconsciously in our mind as a result of our physical experience in this three dimensional world. Each schema is a structured whole, based on human physical existence" (Shinichiro, 2000, p. 16). Thus, having heard the word "cleaner" we imagine unconsciously a woman, usually with a duster, who cleans. A visual image figures in our mind the shape of an object; an auditory image representing the sound she makes can be formed later. The visual and auditory images search 
for the morphological structure of the word: verb + suffix of an agent -er $(\mathrm{V}+$-er $\rightarrow \mathrm{N})$, which is necessary for outlining this image during the communication process. It should be noted that languages have different images because they have different grammatical structures.

To use the necessary morphological structure, we choose some image of the perceived situation in our mind. This image is a schema or a frame that depends on our cognition, knowledge, and experience. It is therefore advisable to consider the term "frame" in more detail in connection with the morphologic structure of a word.

Frames are patterns that form certain relations in our mind. The term "frame" was firstly introduced as a conceptual instrument by M. Minsky who presented it as a cover term for "a data-structure representing a stereotyped situation" (Minsky, 1975, p. 212). Many linguists have investigated frames from different aspects: E. Goffman, D. Tannen, Ch. Fillmore, to M. Petruck, Y. Matsumoto, V. Demyankov, O. Kubriakova. M. Polyuzhyn, S. Zhabotynska and others. Having analyzed different approaches to a frame, we can outline the following characteristics of a frame:

- it represents categorization processes of consciousness during a person's cognition of the real world;

- this structure joins together language and extra-language experience in a person's consciousness;

- it is the representation of a certain situation (scene) or concept (script), which is imprinted in a person's consciousness in the form of experience and can be reproduced again under similar circumstances;

- it structures the concept organization of a person's knowledge and experience;

- it is closely connected with semantic knowledge relating to the specific concept it refers to;

- it is a knowledge structure for the interpretation of different kinds of grammatical constructions (including morphological structures). It helps construct grammatical constructions through understanding the intimate relationship between syntax, morphology, and semantics, depending on a person's cognition, knowledge, and experience.

Considering the above-mentioned characteristics of a frame, we can use frame patterning for explanation of cognitive mechanisms influencing the formation and functioning of different morphological units. According to S. Zhabotynska's classification of frames (object-centered, actional, partonymic, associative, and hyponymic frames (Жаботинская, 1999, p. 16), we have established a direct relationship between a derivational morpheme and a frame pattern: the object-centered frame correlates with the most adjective suffixes and prefixes as it ensures characteristics of an object (agent) by quantitative, existansive, locational, temporary , and evaluation parameters; the associative frame correlates only with adjective suffixes with the meaning of likeness and resemblance $-l y,-y,-l i k e,-i s h,-$ ous, -ar/-or; the partonymic frame pattern is represented by only two prefixes sub- and semi- with the meaning of some part or subdivision.

Frame patterns represent a person's cognitive knowledge by joining together his/her language and extra-language experience to denote a certain situation or concept through different morphological structures. The choice of the morphological structure of a word depends much on the type of a frame pattern.

Thus, the cognitive approach to the investigation of the morphological structure of words allows explaining language as a complex system with its own universal principles that govern its organization and use and depend on mental characteristics of people. The knowledge of morphological properties of language can help gain some understanding of the specific characteristics of human mind. Cognitive morphology deals with defining cognitive mechanisms influencing the morphological structure of words. It has its own principles, which we should take into consideration while analyzing the morphological structure of words.

Cognitive morphology like cognitive grammar has imaginary character as we choose a certain 
image to outline the perceived situation in the communication process. These images are represented in our mind by frames defined as patterns that form certain relations in our mind. Different types of relations require different frame patterns (object-centered, actional, partonymic, associative, and hyponymic ones). The knowledge of a frame pattern can help choose the necessary morpheme to form a word. The cognitive mechanisms influencing the morphological structure of words of different terminological systems can be the area for future study.

\section{СПИСОК ВИКОРИСТАНИХ ДЖЕРЕ $\Lambda$}

Жаботинская С. А. Концептуальный анализ: типы фреймов. Вісник Черкаського університету. Серія: Філологічні науки. Черкаси : ЧДУ, 1999. Вип. 11. С. 12-25.

Полюжин М. М. Функціональний і когнітивний аспекти англійського словотворення : монографія. Ужгород : Закарпаття, 1999. 240 с.

Chomsky N. Reflections on language. N.-Y. : A Division of Random House, 1975. 266 p.

Lakoff G., Johnson M. Philosophy in the flesh. The embodied mind and its challenge to western thought. N.-Y. : Basic Books, 1999. 640 p.

Langacker R. W. Foundations of cognitive grammar: Theoretical prerequisites. V. I. Stanford : Stanford University Press, 1987. 516 p.

Minsky M. A framework for representing knowledge. The Psychology of Computer Vision. (Ed. by Patrick Henry Winston). N.Y. :Mc. Grow-Hill, 1975. P. 211-277.

Shinichiro Kodani. English words: Word-formation and evaluative words. [Kyoto]: Ryukoku Gakkai, Ryukoku univ., 2000. 11, 283 p.

\section{VALENTYNA VOSKOBOINYK}

\section{THE STUDY OF THE MORPHOLOGICAL STRUCTURE OF WORDS WITHIN THE} FRAMEWORK OF COGNITIVE MORPHOLOGY

The article considers the basics of the cognitive approach to the analysis of language units. The purpose of the article is to establish the basic principles of cognitive morphology, which are based on the principles of cognitive grammar and which can be used for the analysis of the morphological structure of any word. They are the following: morphological units should be investigated in the light of human experience, cognitive processes of man and his/her vision; morphological units have prototype structures; the morphological structure of a word from a certain language depends on the peculiarities of this language; grammatical rules depend partially on semantic properties of lexical units; semantic structures should be characterized with the reference to the ways of interiorisation of reality; conventional links among morphological structures are identified through metaphoric and metonymic processes; cognitive morphology is of imaginary character. It is proposed to use the technique of frame patterning to analyze the morphological structure of the word. The choice of the morphological structure of a word depends on the type of a frame pattern. This study will be useful for those who are in line with a new approach to the analysis of language units - cognitive morphology.

Key words: cognitive grammar; cognitive morphology; morpheme; frame; frame patterning; cognitive mechanisms.

\section{REFERENCES}

Chomsky, N. (1975). Reflections on language. N.-Y.: A Division of Random House.

Lakoff, G., \& Johnson, M. (1999). Philosophy in the flesh. The embodied mind and its challenge to western thought. N.-Y.: Basic Books.

Langacker, R. W. (1987). Foundations of cognitive grammar: Theoretical prerequisites. V.I. Stanford: Stanford University Press.

Minsky, M. (1975). A framework for representing knowledge. In Patrick Henry Winston (Ed.), The Psychology of Computer Vision (pp. 211-277). N.Y.:Mc. Grow-Hill.

Polyuzhyn, M. M. (1999). Funktsionalnyi i kohnityonyi aspekty anhliiskoho slovotvorennia [Functional and cognitive aspects of English word-formation]: monohrafiya. Uzhhorod: Zakarpattya [in Ukrainian]. Shinichiro, Kodani. (2000). English words: Word-formation and evaluative words. [Kyoto]: Ryukoku Gakkai, Ryukoku univ.

Zhabotynskaya, S. A. (1999) Kontceptualnyi analiz: tipy freimov [Conceptual analysis: types of frames]. Visnyk Cherkaskoho universytetu. Seriya: Filolohichni nauky [Bulletin of Cherkasy University: Series: Philological Sciences], 11, 12-25 [in Russian]. 